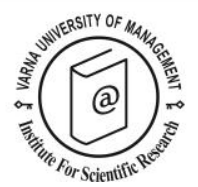

\title{
Understanding the role of destination imagery in mountain destination choice. Evidence from an exploratory research
}

\author{
Arthur Araújo ${ }^{1}$, Lucília Cardoso ${ }^{2 *}$, Noelia Araújo ${ }^{3}$ and Francisco Dias ${ }^{4}$
}

Received: 15/06/2018 Accepted: 21/12/2018

\begin{abstract}
1 Department of Economy, Management, Industrial Engineering, and Tourism, University of Aveiro Campus universitário de Santiago, 3810-193, Aveiro, Portugal. E-mail: arthurfilipearaujo@gmail.com

2 CITUR - Centre for Tourism Research, Development and Innovation, Portugal. E-mail: lucyalves.lucilia@gmail.com

${ }^{3}$ Business Management and Marketing Department, University of Vigo, Business and Tourism Faculty, 32004, Ourense, Spain. E-mail: naraujo@uvigo.es

${ }^{4}$ CITUR - Centre for Tourism Research, Development and Innovation, and Leiria Polytechnic, Santuário de N. Senhora dos Remédios 2520-641 Peniche, Portugal. E-mail: francisco.dias@ipleiria.pt.

* Corresponding author
\end{abstract}

Coordinating editor: Stefano Duglio and Riccardo Beltramo

\begin{abstract}
The present study explores the imagery of mountain tourism destinations. The research is based on customer-based brand equity and destination choice models, and addresses destination imagery through the concepts favourite destination (FD) and autobiographical memory. Through an online, multilingual survey, 711 responses, consisting of words, associated by a self-selected sample of European mountain tourists to their favourite mountain destinations, were collected. Such data was subjected to a deductive content analysis, and the results suggest that the imagery of favourite mountain destinations consists mostly of functional elements. Findings reinforce previous theories regarding the concept of favourite destinations, destination imagery (DY) processing, and destination choice. Future studies should apply such analysis to other tourism products, as well as to different or more representative samples, to verify whether imagery structures differ.
\end{abstract}

Keywords: Mountain Tourism; Destination choice; Destination Imagery (DY); Favourite Destination (FD); Customer-based Brand Equity.

Citation: Araújo, A., L. Cardoso, N. Araújo and F. Dias (2019) Understanding the role of destination imagery in mountain destination choice. Evidence from an exploratory research. European Journal of Tourism Research 22, pp. 151-165

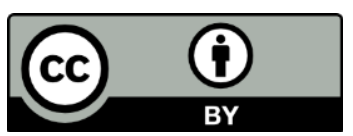

RESEARCH PAPER
This work is licensed under the Creative Commons Attribution 4.0 International (CC BY 4.0). To view a copy of this license, visit https://creativecommons.org/licenses/by/4.0/ 
Understanding the role of destination imagery in mountain destination choice. Evidence from an exploratory research.

\section{Introduction}

There has been a slow but steady effort towards increasing global awareness concerning mountain issues (Nepal \& Chipeniuk, 2005). Until very recently, tourism studies concerned with mountain landscapes were mainly limited to physical, ecological, and environmental processes (Smethurst, 2000). However, an increasing number of researchers is interested in mountain tourism destinations (Beedie \& Hudson 2003; Dornier \& Mauri, 2018; Godde, Price, \& Zimmermann, 2000; Mateiro, Kastenholz, \& Breda, 2018; Nepal, 2002; Nepal \& Chipeniuk, 2005; Ponjiger, 2018; Price, Moss, \& Williams, 1997). The segment is considered an important part of the tourism sector, as has been gaining popularity worldwide (Schneider, 2010).

Mountains cover $24 \%$ of the Earth's surface. They are present in a total of 139 countries throughout all continents. Mountains are also in many types of ecosystems, including deserts, polar areas, and tropical forests (Richins, Johnsen, \& Hull, 2016). Mountain tourism currently represents up to $20 \%$ of trips globally (Buckley, 2007; Silva, Kastenholz, \& Abrantes, 2015). Visitors to mountain regions seek contact with both the natural and the social environment, as well as to fulfil their need to "escape" from everyday life (Moira \& Drivas, 2017).

Mountain facility managers should follow up and monitor market changes when appropriate, in order to be prepared to respond to new needs (Bonadonna, Giachino, \& Truant, 2017). Therefore, from a destination competitiveness perspective, it is important to understand what travellers seek in a mountain tourism destination. The actors of the tourism industry, particularly in mountainous regions, have had a clear and applied approach in relation to the development and provision of quality and interactive services (Richins, 2016). Moreover, it should be considered that mountain tourism development has been influenced by recent changes in the tourism sector, which have brought about new challenges. According to Keller and Bieger (2010), those challenges are caused by ecological - including climate change -, social, cultural, economic, and political (i.e., construction laws) changes.
Those changes cause a shift in the environments and resources in which tourism has relied, as well as in the companies included in the tourism value chain (i.e., lead of management change), and in their motivation or ability to control external elements. In this context, many companies have sought to provide tourists with meaningful experiences in the mountain tourism scenario (Richins, 2016).

The present work addresses this topic via the concept of favourite destination, i.e., a place one has already visited, and considers the best destination for a certain type of tourism (Dias \& Cardoso, 2017). Therefore, the study's goal is to explore what makes a favourite mountain tourism destination. Such question is addressed through theories of destination imagery (DY) processing and autobiographical memory. DY refers to the processing of destination image (DI) elements in the working memory, which is the short-term memory and includes the evocation and retrieval of information from the long-term memory (Maclnnis \& Price, 1987; Miller, Hadjimarcou, \& Miciak, 2000). The autobiographical memory is, simply, a person's recollections of past experiences and behaviours, and when applied to a previously visited destination, includes the tourist's memorable experiences in situ. Therefore, when thinking about their favourite destination (FD), a tourist retrieves imagery elements from his/her autobiographical memory.

To operationalise such concepts, words associated by mountain tourists to their favourite mountain tourism destinations were collected through an online multilingual survey. The method relied on free-recall techniques and ensued a total of 711 responses from European tourists. Findings reinforce recent theories about destination imagery processing, destination choice, and favourite destination. Moreover, they bring about relevant insights for mountain destination managers.

\section{Literature review}

\section{Mountain tourism destinations}

Mountain tourism has evolved from attractions of local interest to internationally recognised destinations that play an important role in the tourism sector for mountainous areas or 
regions (Nepal, 2011). Worldwide known examples are the Himalayan peaks, such as Everest and Annapurna (Babu, Mal, \& Kala, 2009; Dar, Rashid, Romshoo, \& Marazi, 2014; Geneletti \& Dawa, 2009; Mu \& Nepal, 2016), which are amongst the major tourist attractions of Nepal (Nepal, 2011). The attractiveness of the mountains is not a recent trend, as they have always drawn pilgrims, explorers, and adventurers. In Japan, for example, mountains were first considered sacred places. During the early modernisation phase, the mountains and their secluded valleys witnessed drastic changes as they became objects of conquest and, later, places of touristic interest (Chakraborty, 2018).

The first known mountain tourism guide dates back to late 18th century, in the Alps. Another landmark in publications on this sector is first monographic book dedicated to the Pyrenees, written by Ramond de Carbonnières, and published in 1789 (Martínez de Pisón, 2004; Nogué, 2005, Saule-Sorbé, 2007). By the late 19th century, mountains in Malaysia started attracting, besides climbers - their usual frequenters -, diabetes experts, who searched for wildflowers and plants in the highlands (Yunus, 2005). From then on, the taste for the mountain has constantly increased. Motivations are typically associated with health benefits and outdoor activities (i.e., climbing, trekking, backpacking, hiking, skiing or wilderness activities), and the increasing demand made organisers view the segment as economically viable (Hajar, Jamal, Sumarjan, \& Aminudin, 2015).

Mountain tourism is currently part of many packages offered by national and international tour operators (Hajar et al., 2015). This is the case of the Alps, one of the Europe's major mountain destinations. Located between two zones of high demographic density - the Rhine countries in the north, and northern Italy in the south - The Alps cover an area of 190,000 $\mathrm{km}^{2}$, with a population of 15 million., (Agrawala, 2007). The region is one of the most visited destinations in the world, as it receives between 60 and 80 million tourists annually, that is, six times its own local population. (Agrawala, 2007). Tourist activity generates about 50 million euros per year, and is responsible for $10 \%$ to $12 \%$ of local jobs (Abbeg, Agrawala, \& Crick, 2007). The type of mountain tourism developed in the Alps has become a trend, which influenced the development of the activity in other emerging destinations, such as Serbian mountain regions (Milijić, Mićić, \& Maksin, 2017). Those trends include winter sports, particularly skiing, which is the core offer of most winter mountain destinations. The Alps offer around 600 ski resorts and 10.000 skiing facilities, which makes it Europe's main ski destination (Abbeg et al., 2007). Therefore, alpine tourism plays a major contribution in the economies of the countries throughout which the region extends: France, Italy, Switzerland, and Austria.

When addressing mountain tourism, particularly when winter sports are the main attraction, there is an important factor that must be considered: climate change (Agrawala, 2007; Unbehaum, Pröbstl, \& Haider, 2008). By the end of the 1980 decade, a period of years with snowless winters in the Alps gave those countries an idea of what climate change could mean for winter sports-based tourism. The absence of snow leads to a massive wave of cancellations. Therefore, skiing zones must be prepared for such phenomenon, which means their planning must include reactive actions for such scenario. Those might include: adaptation measures for winter sports (i.e., artificial snow), compensation payments to clients in case of insufficient snow, in order to maintain their loyalty; and development strategies to strengthen the summer season (Unbehaum et al., 2008).

Besides winter sports, tourists also increasingly seek for authentic and comprehensive experiences in mountain areas (Malasevska, 2018; Mauri \& Turci, 2018). In both cases, the natural and social environments play a significant role in tourists' experiences (Moira \& Drivas, 2017). Therefore, fomenting residents' Environmental Conservation Behaviour (ECB), as a way of promoting sustainable tourism development in mountainous regions, is of utmost importance (Zhang et al., 2017). Additionally, it must be considered that mountain destinations also compete with each other, as well as with other alternative destinations. Therefore, besides offering good 
conditions for winter sports and meaningful experiences, destinations also need to be marketed as a suitable choice for potential tourists.

In this context, destination marketers strive to design outstanding marketing campaigns to induce positive images (Önder \& Marchiori, 2017), and thus, place destinations in tourists' top of mind (Stepchenkova \& Morrison, 2008). In this context, inducing destination image has become a key element in attracting visitors (Martichiello \& Carvalho, 2016). Therefore, the topic has received plenty of attention from academic researchers (Stylos, Bellou, Andronikidis, \& Vassiliadis, 2017), who explore, among other aspects, the role of destination imagery in the destination choice process.

\section{Tourist destination choice}

A critical success factor for tourism destinations is the way tourists perceive them (Kozak \& Rimmington, 1999; Leung \& Baloglu, 2013; Woodside \& Lysonski, 1989). A crucial problem, especially for lesser known destinations, is the fact that prospective tourists are aware of only a certain set of destinations, which constitutes their awareness set (Um \& Crompton, 1990). Moreover, they only have a limited amount of information about these destinations. It is this limited set of information that shapes their image and attitude dimensions of places, which are likely to be critical for their choice of future destinations, wheatear or not they correspond to the truth (Um \& Crompton, 1990).

\section{Previous tourism studies include several} models that attempt to structurally conceptualise the process of destination choice. In the case of skiing destinations, for example, previous studies suggest that intrapersonal, interpersonal and structural constraints influence the development of skiers' stage-based attitudinal loyalty (attraction) (Alexandris, Du, Funk, \& Theodorakis, 2017). In general, destination choice models describe potential tourists' choice as a flowchart that resembles a funnel (Decrop, 2010; Um \& Crompton, 1990; Woodside \& Lysonski, 1989), and recognise that such selection process is heavily based on the way places are represented in people's minds. Considering this, concepts like destination branding are key issues for destination managers, and consequently became popular topic in tourism research (Cai, 2002; Keller, 1993, 2008, 2016; Konecnik \& Gartner, 2007; Yoon \& Uysal, 2005).

Studies on these two topics - destination image and destination branding - have historically been considered as independent lines of research. However, there has recently been a trend towards viewing these topics in an integrated fashion. Qu, Kim, and Im (2011), for instance, states that a destination's overall image (in other words, its brand image) mediates the relationship between its brand associations and tourists' future behaviour. Another example is provided by Konecnik and Gartner (2007), who build on Keller's (1993, 2008,2016 ) work to propose the concept of customer-based brand equity for tourism destination (CBBE-TD), which consists of four interrelated components: destination brand awareness (DBA), destination image (DI), perceived quality $(\mathrm{PQ})$, and destination loyalty (DL). In this context, DBA expresses how highlighted a destination brand name is in a tourist's mind (Aaker, 1996); DI is the sum of associations a tourist has with a given destination; PQ consists in customers' overall perception regarding the quality of products or services in comparison to the competition (Aaker, 1996); and DL reflects a tourist's attachment to the destination brand.

Upon a brief examination, the relationship between destination choice and CBBE-TD seems evident, however, attempts to integrate those constructs in a conceptual framework are extremely scarce. A rare example is provided by Dias and Cardoso (2017), who propose the destination brand choice (DBC) model, which highlights the four CBBE-TD components along the destination choice flowchart, as originally proposed by Decrop (2010). The path proposed by Decrop (2010) (consideration $\rightarrow$ evaluation $\rightarrow$ constraints $\rightarrow$ choice), however, ignores the feedback that happens after the tourist's experience at the chosen destination. Therefore, Dias and Cardoso's (2017) DBC model includes a fifth stage, called the postvisit re-evaluation, recognizing that the quality of one's experience may influence future travel 
decisions. In this context, if a tourist's experience was satisfactory enjoyable, the visited destination might be added to their "favourite set". Accordingly, the destination in which they had their best experience in a certain tourism product becomes their favourite destination (FD) for that type of tourism. Therefore, favourite destination refers to a place one has already visited and considers the best destination for a certain type of tourism.

\section{Destination imagery}

The concept of destination image is sufficiently discussed in the literature (lordanova, 2017). As far as the concept of destaintion imagery is concerned, however, there are still many gaps in literature. The relationship between DI and DY is defined by many authors (Echtner \& Ritchie, 1993; Kim, Kim, \& Bolls, 2014; Kock, Josiassen, \& Assaf, 2016; Matos, Mendes, \& Pintos, 2015), and they agree in several aspects. First, authors' view converge regarding $\mathrm{DI}$ being a global composite to which DY is connected (Matos et al., 2015). It is also broadly acknowledged that DI is not static, as it consolidates in the long-term memory throughout time (Crompton, 1979; Gallarza, Saura, \& García., 2002; Kim, 2017), and is affected by different agents, including organic and induced ones (Gartner, 1994). Moreover, scholars' agree that DY, as a mental process, is responsible for processing and storing information in the working memory (Echtner \& Ritchie, 1993; Kumar \& Nayak, 2014; Matos et al., 2015).

According to psychological models of memory processing (Tetzlaff, Kolodziejski, Markelic, \& Wörgötter, 2012; Zimmermann, Moscovitch, \& Alain, 2016), DY is a momentary process, which lasts no more than several seconds. In this context, it must be observed that DY deals with perceptions (Maclnnis \& Price,1987), as well as with the ideas of symbolic and real and leads potential tourists to imagine their future experiences prior to the trip (Martins, 2015). Considering these concepts, Figure 1. represents a model of the relationship between DI and DY in an individual's memory. Such conceptualisation is based on DI formation models (Beerli \& Martín, 2004; Gartner, 1994) and DY theories (Echtner \& Ritchie, 1993; Maclnnis \& Price,1987), cognitive psychology theories (Steinmetz, Schmidt, Zucker, \& Kensinger, 2012), and physiological models of memory processing (Tetzlaff et al., 2012; Zimmermann et al., 2016).

As systematised in the model, when a given stimulus is detected by the sensory memory, attention is called in the working memory (also called short-term memory). According to Zimmermann et al. (2016), the working memory's representation of received stimuli

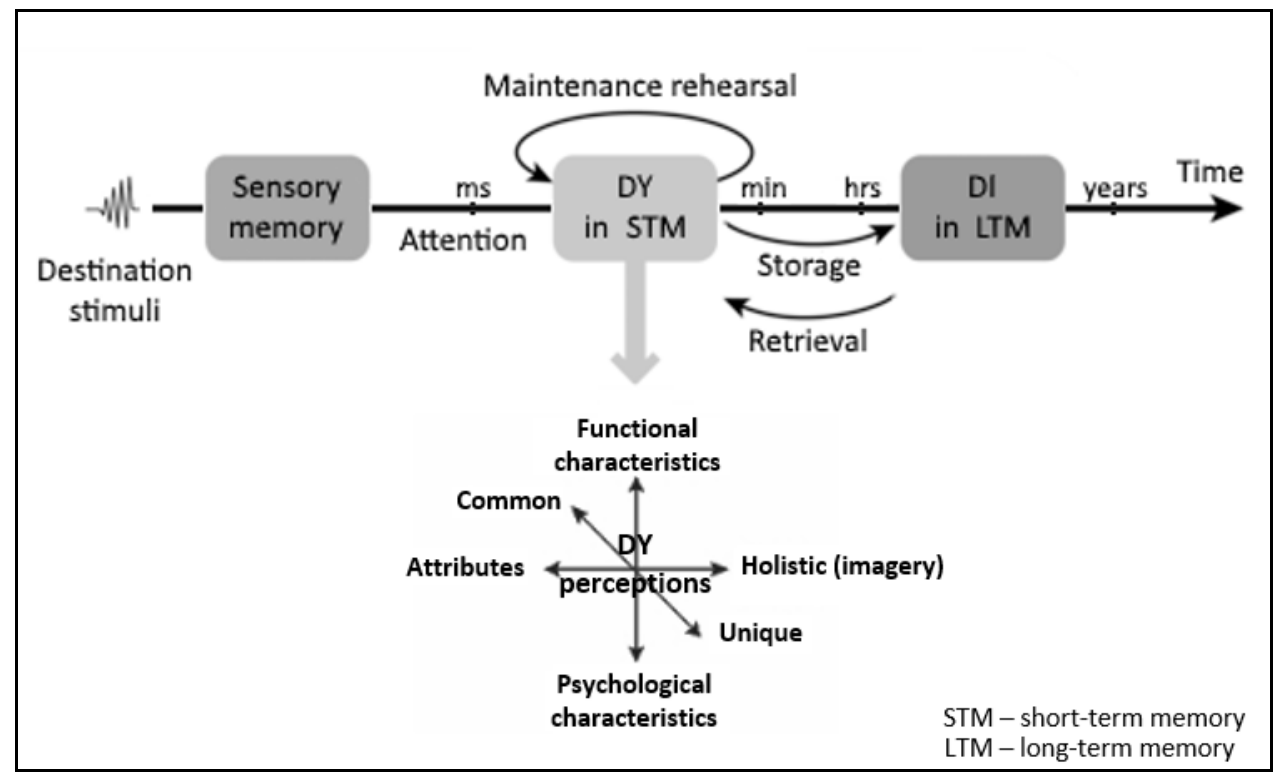

Figure 1. DI and DY in memory

Source: adapted from Echtner and Ritchie (1993), Tetzlaff et al. (2012) and Zimmermann et al. (2016) 
lasts 10 to 30 seconds. Therefore, DY processing involves brief representations of sensory information (Kim et al., 2014), and varies according to whether the stimulus is visual, auditory, gustatory, olfactory, tactile or a combination of several of those categories. Such process also includes the retrieval of DI, which consists in evoking information from the long-term memory, and is also comprised within the mentioned 10 to 30 seconds time frame. In this context, if the person has already visited the destination, the evoked information will include sensorial experiences (Lin \& Huang, 2009), and thus, will be evoked from his/her autobiographical memory. In this context, Kim et al. (2014) argue that DY processing takes place through dual-coding, i.e., a process encompassing both encoding and retrieval of information from the long-term memory. Accordingly, Kumar and Nayak (2014) add that holistic or gestalt information representation methods are the main components of imagery.

Considering the addressed contributions, it can be inferred that DY cannot be directly measured, however, it is potentially an effective tool to access momentary perceptions of destination image. At the same time, despite decades of research in tourism, there is not yet a general agreement regarding DI measurement (Kock et al., 2016). In this context, using the concept of destination imagery to access perceptions that shape destination image presents a potential to generate a significant contribution to tourism theory, as it might aid researchers' comprehension of the structure of DI, and thus, contribute to reaching a common measurement model for this construct.

\section{Methodology}

\section{Data collection}

The present work relied on data provided by travellers from European countries, consisting of words they associate to their favourite mountain destinations. Data was collected throughout the year 2016, through the Tower of Babel project - http://favouritedestinations. com/en/ -, a purpose developed, online, multilingual platform, focused on qualitative data collection, that allows for global, large scale qualitative surveys. The survey used free recall techniques, and was made available in 25 European languages.

For the operationalisation of favourite mountain destinations, as suggested by Echtner and Ritchie (1993), open questions were employed to grasp holistic impressions, characteristics and auras. Accordingly, as suggested by Kock et al. (2016), qualitative, non-structured methodologies were used to grasp unique attributes. Bearing this in mind, the questionnaire employed a two-step approach: first, respondents indicated their favourite mountain destination; then, they were asked to describe the selected destination using three words. The questionnaire included a clarification about the concept of favourite destination, which explained that the term referred to a place the respondent had already visited and considers the best destination for that type of tourism.

It must be noted that the survey did not restrict the choice of destination to any geographical or administrative category, such as city, region, country, island, etc., aiming to avoid influencing respondents' free recall. Data collection was carried out with the active support of 35 teammates that cooperate in the framework of the EATSA - Euro-Asia Tourism Studies Association (www.eatsa.pt). Each partner was responsible for carrying out data collection in his/her own native language, which allowed for the collection of responses in all the 25 European languages supported by the platform.

\section{Data analysis}

The collected data was subjected to deductive content analysis (Marshall \& Rossman, 1995), performed through a variable-oriented approach (Lofland \& Lofland, 1984; Miles \& Hauberman, 1994), which pursued the technique's heuristic function, that is, to enrich the exploratory attempt (Bardin, 2000). The analysis process included two main steps: the elaboration of a coding matrix, and the codification of data into the matrix's categories. Words were adopted as the registry unit, and frequency was the main enumeration rule for coding. 
The coding structure, which was based on Echtner and Ritchie's (1993) framework, included four categories: Functional-holistic, Functional-attribute, Psychological-holistic, and Psychological-attribute. Functional-holistic refers to words that refer to tangible aspects that integrate respondents' general associations with the destination. Functionalattribute includes words referring to tangible characteristics that qualify punctual aspects that are comparable among destinations. Psychological-holistic refers to intangible aspects that integrate tourists' overall mental image of the destination. Finally, psychological attribute refers to elements that, although intangible, qualify aspects that are common to all destinations. The common-unique axis was not considered in the analysis, since, after a pre-analysis of the collected data, it was concluded that virtually all words evoked fell into the common end, which is transversal to the other dimensions. Therefore, for the sake of parsimony, neither common nor unique were included into the dimension combinations within the analysis.

Regarding the specific steps carried out in the analysis process, first, a frequency count of destinations and respective associated words was carried out using QSR NVivo 11 pro. Then, terminologies and the use of initials were standardised throughout the lists of words and destinations. In a second moment, aiming at ensuring results' trustworthiness, an inter-rater reliability analysis of codification was carried. To this end, five post-graduate students acted as coders (independent judges) and received the top 100 words ranked by frequency. The research team member responsible for all the coding procedures also integrated the group of judges. All six judges received instructions about the categorisation model, and explanations regarding the coding procedure. Once the coding process was completed, the six coded files were integrated in one common file, which was submitted to a reliability analysis, using Krippendorff's Alpha (Hayes \& Krippendorff, 2007; Krippendorff, 2004), measured through a macro developed by Hayes for IMB SPSS. The obtained K'Alpha coefficient was 0.91 , which is far above the minimum criterion.
After the inter-rated reliability procedures, the data analysis moved on to the coding of the full semantic material, which was also done using NVivo. To this end, the words were inserted in the matrix's node to which they were conceptually related, according to the previously executed coding and reliability test. The results of such process produced a coding structure from which conclusions regarding the processing of favourite mountain tourism destinations' imagery were drawn.

\section{Results}

\section{Data overview}

A total of 711 European mountain tourists took part in the survey through the Tower of Babel project. The sample includes responses form many European countries, however, France is significantly more represented than any other country, with $31 \%$ of the total sample, followed by Portugal (15\%) and Spain (10\%). On the other hand, central and eastern European countries are not far behind, as they are represented in the following three positions by Poland (9\%), Albania (8\%) and Greece (5\%). Table 1 presents the sample characterisation according to gender and country of origin. Of all destinations chosen by respondents, $43 \%$ refer to towns, cities, or other local entities; $23 \%$ refer to regions within countries, $20 \%$ refer to regions including several countries, $13 \%$ refer to countries, and only $1 \%$ refer continents (see Table 2). Regarding the range of travel, $68 \%$ of chosen destinations are domestic to respondents, that is, in their own country of residence. Meanwhile, only 32\% were international destinations. Amongst those, most destinations $(74 \%)$ were intracontinental, while only $26 \% \quad(5 \%$ of the total) required intercontinental travelling (see Table 3).

Concerning the specific destinations selected by respondents, the Alps is the most mentioned, with 107 occurrences, which represents $15 \%$ of total choices. In second place is the Pyrenes (28 mentions: $4 \%$ ), which is followed by Switzerland (24 mentions: $3 \%$ ), Tatry (Slovakia/Poland: 23 mentions/3\%), Zakopane (Poland - 22 mentions: 3\%), Austria (16 mentions: $2 \%$ ), Bieszcady (Poland: $2 \%$ ), Gerês (Portugal/Spain - 12 mentions: 2\%), Theth (Albania - 12 mentions: $2 \%$ ), and France (11 mentions: $2 \%$ ). As mentioned in the data 
collection section, the questionnaire did not limit the choice of destination to any geographical or socio-political scale, in order to avoid influencing respondents' free recall, hence the mix of towns, regions and countries within the mentioned places. The top 10 destinations are ranked by frequency of mentions in Table 4.

Table 1. Respondents' country of residence by order of frequency

\begin{tabular}{lcc}
\hline Gender & $\mathbf{N}$ & $\mathbf{( \% )}$ \\
Female & 334 & 46,98 \\
Male & 377 & 53,02 \\
Country of Origin & & \\
France & 220 & 30,94 \\
Portugal & 107 & 15,05 \\
Spain & 71 & 9,99 \\
Poland & 64 & 9,00 \\
Albania & 57 & 8,02 \\
Greece & 36 & 5,06 \\
Germany & 28 & 3,94 \\
Italy & 28 & 3,94 \\
Lithuania & 21 & 2,95 \\
Hungary & 21 & 2,95 \\
Bulgaria & 14 & 1,97 \\
Croatia & 7 & 0,98 \\
Others & 37 & 5,06 \\
\hline
\end{tabular}

Table 2. Geographical scale of chosen favourite mountain destinations

\begin{tabular}{lcc}
\hline Destinations' & $\mathbf{N}$ & $\mathbf{( \% )}$ \\
geographical scale & 306 & 43,04 \\
Local & 166 & 23,35 \\
Regional & 142 & 19,97 \\
Multinational & 95 & 13,36 \\
National & 2 & 0,28 \\
Continental & \\
\hline
\end{tabular}

Table 3. Range of travel between chosen favourite mountain destinations and respondents' place of residence

\begin{tabular}{cccc}
\hline Range of travel & $\mathbf{N}$ & $\begin{array}{c}\% \text { of } \\
\text { total }\end{array}$ & $\begin{array}{c}\% \text { of } \\
\text { outgoing }\end{array}$ \\
Domestic & 484 & 68,07 & - \\
Outgoing & 227 & 31,93 & - \\
$\quad$ Intracontinental & 23,77 & 23,77 & 74,45 \\
Intercontinental & 8,16 & 8,16 & 25,55 \\
\hline
\end{tabular}

In terms of the words evoked to describe destinations, nature figures on the top of the list, being mentioned by $5.6 \%$ of respondents. Also in a highlighted position is beauty, with, with $5.34 \%$, followed by landscapes, skiing, snow, mountains, hiking and tranquillity Table 5 summarises the top 20 evoked words.

Table 4. Top 10 mountain tourism destinations mentioned for European tourists

\begin{tabular}{cccc}
\hline RANKING & $\begin{array}{c}\text { MOUNTAIN } \\
\text { DESTINATION }\end{array}$ & $\mathbf{N}$ & $\mathbf{( \% )}$ \\
$\mathbf{1}$ & Alps & 107 & 15,05 \\
$\mathbf{2}$ & Pyrenees & 28 & 3,94 \\
$\mathbf{3}$ & Switzerland & 24 & 3,38 \\
$\mathbf{4}$ & Tatry & 23 & 3,23 \\
$\mathbf{5}$ & Zakopane & 22 & 3,09 \\
$\mathbf{6}$ & Austria & 16 & 2,25 \\
$\mathbf{7}$ & Bieszczady & 13 & 1,83 \\
$\mathbf{8}$ & Gerês & 12 & 1,69 \\
$\mathbf{9}$ & Theth & 12 & 1,69 \\
$\mathbf{1 0}$ & France & 11 & 1,55 \\
\hline
\end{tabular}

The structure of mountain destinations' imagery The words evoked by respondents to describe their favourite mountain destinations were classified within a framework based on Echtner and Ritchie's (1993) dimensions, amongst which functional holistic is clearly the dominant category, as showed in Figure 2. The dimension includes words like nature, landscapes, and snow, all within the top 5 evoked words. The next most comprehensive dimension was functional attributes, which included mentions to the weather, the quality of food, water, air, and prices. It must be observed here that, as per the results of the reliability test mentioned in the data analysis section, words referring to mountain sports were included in this category, as most judges interpreted them as an evaluation of the mentioned destinations regarding its adequateness, or the quality of its environment, for the practice of that sport. In this context, the dimension includes words like skiing, hiking, and sports, as well as others like green, which is also an attribute of the place's natural environment.

Psychological holistic is the second least comprehensive dimension, and included beauty, tranquillity, adventure and peace, which can neither be objectively measured nor directly compared among destinations. Finally, the dimension that includes the smallest amount occurrences is psychological attribute, which includes, basically, all words referring to subjective qualifications, such as relaxing, and amazing. 
Araújo, A., L. Cardoso, N. Araújo and F. Dias (2019) /. European Journal of Tourism Research 22, pp. 151-165

Table 5. Top 20 words used to describe mountain destinations by European tourists

\begin{tabular}{llccll}
\hline Word & Count & $\begin{array}{c}\text { Weighted } \\
\text { Percentage (\%) }\end{array}$ & Category & Similar Words \\
\hline 1 & Nature & 184 & 5.65 & Functional holistic & natural \\
2 & Beauty & 174 & 5.34 & Psychological holistic & beautiful, beautifully \\
3 & Landscapes & 144 & 4.42 & Functional holistic & landscape, landscaped \\
4 & Skiing & 129 & 3.96 & Functional attribute & ski \\
5 & Snow & 121 & 3.72 & Functional holistic & - --- \\
6 & Mountains & 100 & 3.07 & Functional holistic & mountain, mountaineering, \\
7 & Hiking & 79 & 2.43 & Functional attribute & mountaineers, mountainous \\
8 & Tranquillity & 77 & 2.36 & Psychological Holistic & ---- \\
9 & Cold & 55 & 1.69 & Functional attribute & coldness \\
10 & Adventure & 49 & 1.50 & Psychological holistic & adventures, adventurous \\
11 & Sports & 47 & 1.44 & Functional attribute & sport, sporting \\
12 & Relaxing & 46 & 1.41 & Psychological attribute & relax, relaxed \\
13 & Freshness & 44 & 1.35 & Functional attribute & fresh \\
14 & Air & 43 & 1.32 & Functional holistic & ----- \\
15 & cool* & 29 & 0.89 & Functional holistic & ----- \\
16 & Green & 29 & 0.89 & Functional attribute & ----- \\
17 & Gastronomy & 28 & 0.86 & Functional holistic & ----- \\
18 & High & 27 & 0.83 & Functional attribute & highly, highness \\
19 & Peace & 27 & 0.83 & Psychological holistic & peaceful \\
20 & Amazing & 25 & 0.77 & Psychological attribute & ----- \\
\hline & $*$ Cool referred to the climate, and thus was considered a functional attribute. \\
\hline
\end{tabular}

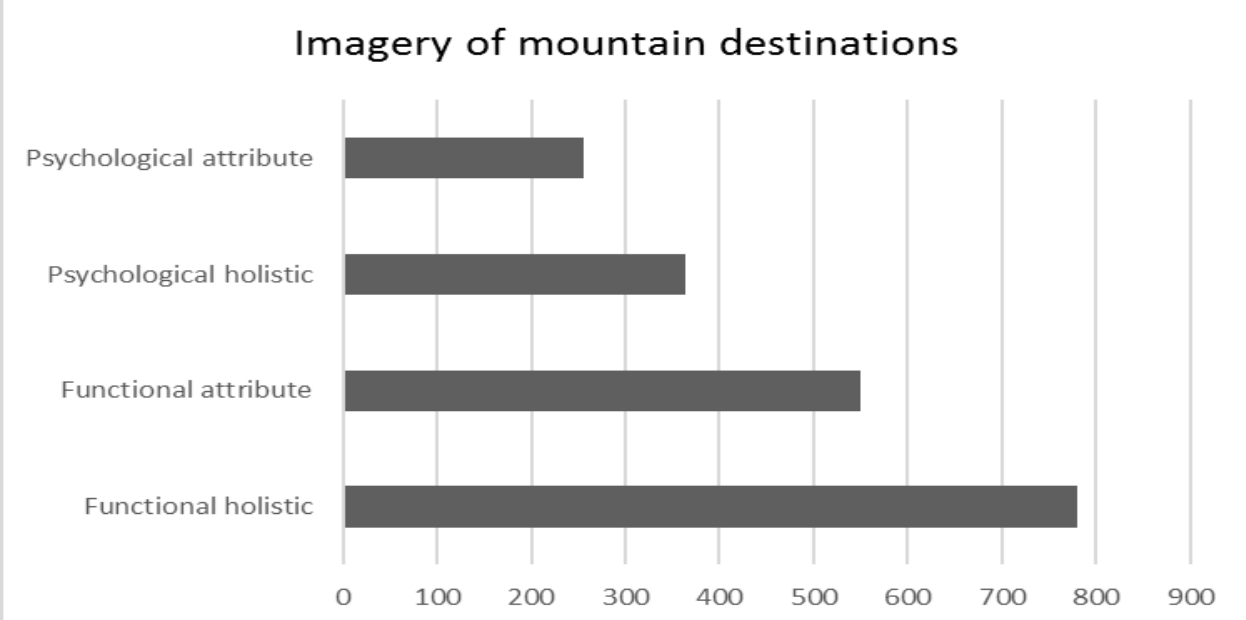

Figure 2. Distribution of favourite mountain destinations' imagery elements within the matrix's categories 


\section{Discussion}

The present study's findings reinforce previous theories regarding the concept of DY and its relationship with destination image, the characteristics and trends regarding favourite destinations, and the destination choice process. Moreover, results suggest specific tendencies for the formation of mountain destinations' imagery.

In terms of contributions for the concept of DY, findings corroborate Echtner and Ritchie's (1993) statement about the relationship between DI and DY, and the latter's more holistic character. This is clearly indicated by the dominant role of the functional holistic category within the words used by European tourists to describe their favourite mountain tourism destinations. Additionally, even within the psychological dimension, which included the two least comprehensive categories, psychological holistic also encompassed significantly more words than psychological attribute.

As for the specific theories related to favourite destinations, findings reinforce Dias and Cardoso's (2017) view, according to which such destinations are relatively close to tourists' place of residence, being typically domestic, or in neighbouring countries. This becomes evident upon a simple examination of the overall statistics. As presented in the data overview, $68 \%$ of selected favourite mountain destinations are domestic, and amongst the international ones, $74 \%$ are intracontinental. Only $0.8 \%$ of the total of destinations require intercontinental travelling.

Regarding destination choice models, findings contribute to determining the elements that provide the basis for the post-visit evaluation, proposed by Dias and Cardoso (2017) as a complement to the destination choice path proposed by Decrop (2010) (consideration $\rightarrow$ evaluation $\rightarrow$ constraints $\rightarrow$ choice). The findings suggest that, in the case of mountain destinations, especially when tourists' experiences in situ are satisfying and enjoyable - and therefore the destination might become their favourite -, such elements are mostly functional.
The overall dominance of the functional dimension is probably explained by the very nature of the destinations, and of the activities they allow tourists to practice. As seen in Table 5 , the list of top 20 words evoked to describe mountain tourism destinations is clearly dominated by attributes and holistic features that are inherent to the geographical characteristics of mountain destinations (e.g., snow, mountains, cold, freshness...) - or more generic ones that describe those features, but could also be used to describe other destinations' characteristics (e.g., nature, beauty, landscapes, tranquillity...) -, and by those referring to the activities that this specific geographical environment allows for (e.g., skiing, hiking, sports). Most of these words fall into the functional dimension, combined with either the attribute of holistic dimension. The exceptions are those that refer to functional holistic items (i.e.: beauty and tranquillity).

Having the results been discussed against the extant literature, the next chapter presents the authors final considerations on the obtained findings, with emphasis on the managerial implications that they bring about.

\section{Conclusions}

The present study aimed at exploring the imagery of favourite mountain tourism destinations, which has been addressed through theories of destination imagery and autobiographical memory. The research built on several theoretical contributions regarding the concept of DY, as well as on psychological theories of mental image formation and imagery processing. Additionally, customerbased brand equity (for tourism destinations) and destination choice models were of key relevance for the research. The study's main results come from a deductive, quantified content analysis of words evoked by way of free recall, associated by European tourists to their favourite mountain destinations. Findings suggest that the imagery of favourite mountain tourism destinations, that is, the elements that tourists evoke from their episodic, autobiographical memory, upon receiving a verbal FD stimulus, fall mostly into the functional dimension. Such dimension includes both holistic features and attributes, whereas the former include significantly more 
occurrences. More precisely, the results show that the mental imagery of European tourists is mostly functional holistic, and the natural beauty of the mountain landscape is the most evoked feature.

These finding provide guidelines for designing new tourism products and advertising themes. In this vein, an interesting result concerns the functional attribute dimension. Words like "skiing" and "hiking", that is, those describing activities, play a highlighted role on favourite mountain destinations' imagery. This reinforces the importance both of winter sports and meaningful experiences as core elements offered by mountain destinations, as pointed out in the literature review. Concerning the insights for mountain tourism destination managers, first, the most intuitive implication is the importance of capitalizing on the place's potential to offer activities that are made possible by the specific geography and natural features of mountainous regions. A second implication is related to seasonality. Activities such as "skiing", for instance, which is the main appeal of many European mountain destinations, are extremely sensible to seasonality. Even bigger challenges are brought by the context of climate change, as a snowless winter may be catastrophic for destinations heavily dependent on skiers. Therefore, balancing the offer with other activities that are less subject to seasonality, or even with summer activities, is a good way of minimizing such problem. The list of evoked words offers an idea of the activities (i.e., hiking and mountain biking) on which destination managers could capitalise to this end.

Another implication that comes from of the holistic functional dimension of the mountain destinations regards "gastronomy", which is one of the most perceived attributes. Gastronomy is indeed always present in the context of travelling, both due to tourists' basic need of eating, and as part of their experience. Although this attribute is often overlooked by destination manager organisations, it can be a key element in redesigning mountain tourism products, especially in the referred context of climate change, in which the original core attributes of such destinations might be threatened by unfavourable meteorological conditions. Additionally, gastronomy can also help to minimise the problem of seasonality in mountain destinations.

Psychological elements, both holistic and attributes, are also present, however in a smaller scale. The authors believe that such specific configuration is particular to destinations whose primary attractiveness is mostly inherent to their geographical features. Such belief is reinforced by the abundance of words that describe or qualify such features as well as the activities they allow for - within the top 20 most evoked words. Therefore, the imagery of favourite city or cultural destinations, for instance, would probably present a less relevant role of functional attributes, which, within the present investigation, mostly referred to mountain sports, and a greater relevance of psychological holistic elements.

Although psychological elements in general represent a smaller proportion of the evoked words, it is noticeable that psychological holistic elements outnumber psychological attributes. Such result provides a relevant contribution to mountain destinations' planning and marketing. Perceptions such as "peaceful" and "adventure", for instance, must be considered when designing and promoting mountain tourism products, as they allude to the type of experiences tourists seek in the destination, as pointed out by Malasevska (2018) and Mauri and Turci (2018). Knowing the importance of such elements, destination managers should, as pointed out by Gartner (1994), highlight psychological holistic elements in the design and promotion of their products.

Another interesting result is that $68 \%$ of respondents selected domestic destinations as their favourite mountain destinations. This contributes to the comprehension of this segments' behaviour, and decision-making process. The result also brings an implication to the management of destinations access ways, which must be carried out considering the potential relevance of the domestic tourist.

A final managerial implication stems from the study's contribution to destination choice theory, particularly to the post-visit reevaluation. In face the study's findings, 
campaigns aiming to capitalise on repeat visitors should focus on emotional appeals, which in addition to the consciousness of the functional aspects they already have, will increase their likelihood to return.

In sum, as discussed in the previous section, findings reinforce previous theories regarding the concept of DY, its relationship with DI (Echtner \& Ritchie's, 1993), and the characteristics and trends of favourite destinations (Dias \& Cardoso's, 2017). Moreover, results contribute to enhance previous destination choice models. The findings also provide practical contributions, which are of particular relevance for mountain destination managers and marketers.

Despite its originality and contributions, the study also presents limitations, which in turn, point to avenues for future research. Due to the exploratory nature of the investigation, combined with the specificities of mountain tourism destinations, results cannot be extrapolated to other markets (besides the European) of mountain tourism. Moreover, conclusions regarding the imagery of favourite mountain tourism destinations cannot be generalised to favourite destinations for other tourism products. In this context, investigating how the imagery structure changes according to the type of destination and tourism product is a fertile path for future studies. Such investigations could verify the authors' belief regarding the specificity of the imagery structure found in this study to mountain tourism destinations, and its likeliness to differ significantly for other tourism products.

\section{References}

Aaker, D. A. (1996). Building strong brands. The Free Press: New York.

Abbeg, B., Agrawala, S. \& Crick, F. (2007). Climate change impacts and adaption in winter tourism. In Agrawala, S. (Ed). Climate change in the European Alps. Paris: OECD Study.

Agrawala, S. (2007). The European Alps: Location, Economy and Climate. In Agrawala, S. (Ed). Climate change in the European Alps. Paris: OECD Study.

Alexandris, K., Du, J., Funk, D. \& Theodorakis, N. D. (2017). Leisure constraints and the psychological continuum model: a study among recreational mountain skiers. Leisure Studies, 36(5), 670-683.

Babur, R., Mal, S. \& Kala, C. P. (2009). Community responses to mountain tourism: A case in Bhyundar Valley, Indian Himalaya. Journal of Mountain Science, 6(4), 394-404.

Bardin, L. (2000). Análise de conteúdo. Edições 70: Lisbon, ISBN: 972-44-0898-1.

Beedie, P. \& Hudson, S. (2003). Emergence of mountain-based adventure tourism. Annals of Tourism Research, 30(3), 625643.

Beerli, A. \& Martín, J. D. (2004). Factors influencing destination image. Annals of Tourism Research, 31(3), 657-681. https: //doi.org/10.1016/j.annals.2004.01.010.

Bonadonna, A., Giachino, C. \& Truant, E. (2017). Sustainability and Mountain Tourism: The Millennial's Perspective. Sustainability, 9(7), 1219.

Buckley, R. (2007). Adventure tourism products: price, duration, size, skill, remoteness. Tourism Management, 28, 1428-1433.

Cai, L. A. (2002). Cooperative branding for rural destinations. Annals of Tourism Research, 29(3), 720-742.

Chakraborty, A. (2018). Japan's Mountain Tourism at a Crossroads: Insights from the North Japan Alps. Tourism Planning \& Development, 15(1), 82-88.

Crompton, J. L. (1979). Motivations for pleasure vacation. Annals of Tourism Research, 6(4), 408-424.

Dar, R. A., Rashid, I., Romshoo, S. A. \& Marazi, A. (2014). Sustainability of winter tourism in a changing climate over Kashmir Himalaya. Environmental Monitoring and Assessment, 186(4), 2549-2562.

Decrop, A. (2010). Destination choice sets: An inductive longitudinal approach. Annals of Tourism Research, 37(1), 93-115.

Dias, F. \& Cardoso, L. (2017). How can brand equity for tourism destinations be used to preview tourists' destination choice? An overview from the top of Tower of Babel. Tourism \& Management Studies, 13(2), 13-23.

Dornier, R. \& Mauri, C. (2018). Conclusions: managing tourism sustainability in mountain destinations. Worldwide Hospi- 
Araújo, A., L. Cardoso, N. Araújo and F. Dias (2019) /. European Journal of Tourism Research 22, pp. 151-165

tality and Tourism Themes, 10(2), 267273.

Echtner, C. \& Ritchie, J. R. (1993). The measurement of destination image: an empirical assessment. Journal of Travel Research, 31(4). 3-13.

Gallarza, M. G., Saura, I. G. \& García, H. C. (2002). Destination image: Towards a conceptual framework. Annals of Tourism Research, 29(1), 56-78.

Gartner, W. C. (1994). Image Formation Process. Journal of Travel \& Tourism Marketing, 2(2-3), 191-216. https://doi. org/10.1300/J073v02n02_12

Geneletti, D. \& Dawa, D. (2009). Environmental impact assessment of mountain tourism in developing regions: A study in Ladakh, Indian Himalaya. Environmental Impact Assessment Review, 29(4), 229-242.

Godde, P. M., Price, M. F. \& Zimmermann, F. M. (2000) Tourism and Development in Mountain Regions. CABI Publishing: Wallingford, UK.

Hajar, M., Jamal, S. A., Sumarjan, N. \& Aminudin, N. (2015). Examining the structural relations among hikers' assessment of pull-factors, satisfaction and revisit intentions: The case of mountain tourism in Malaysia. Journal of Outdoor Recreation and Tourism, 12, 8288.

Hayes, A. F. \& Krippendorff, K. (2007). Answering the Call for a Standard Reliability Measure for Coding Data. Communication Methods and Measures, 1, 77-89.

Iordanova, E. (2017) Tourism destination image as an antecedent of destination loyalty: The case of Linz, Austria. European Journal of Tourism Research 16, 214-232

Keller, K. L. (1993). Conceptualizing, measuring, and managing customerbased brand equity. Journal of Marketing, 57, 1-22. http://dx.doi.org/10.2307/1252 054

Keller, K. L. (2008). Strategic Brand Management: Building, Measuring and Managing Brand Equity, 3rd ed. Pearson Education: New Jersey.

Keller, K. L. (2016). Reflections on customerbased brand equity: perspectives, progress, and priorities. AMS Review, 6 (1), 1-16.

Keller, P. \& Bieger, T. (2010) (Eds). Managing Change in Tourism. Creating Opportunities-Overcoming Obstacles. Berlin: Erich Schmidt Verlag.

Kim, J. H. (2018). The impact of memorable tourism experiences on loyalty behaviors: The mediating effects of destination image and satisfaction. Journal of Travel Research, 57(7), 856-870,

Kim, S. B., Kim, D. Y. \& Bolls, P. (2014). Tourist mental-imagery processing: Attention and arousal. Annals of Tourism Research, 45 63-76.

Kock, F., Josiassen, A. \& Assaf, A. G. (2016). Advancing Destination Image: The Destination Content Model. Annals of Tourism Research, 61, 28-44.

Konecnik, M. \& Gartner, W. C. (2007). Customer-based brand equity for a destination. Annals of Tourism Research, 34(2), 400-421.

Kozak, M. \& Rimmington, M. (1999). Measuring Tourist Destination Competitiveness: Conceptual Considerations and Empirical Findings. Hospitality Management, 18(3), 273-283.

Krippendorff, K. (2004). Content Analysis: An Introduction to Its Methodology (2nd ed.). CA Sage: Thousand Oaks.

Kumar, V. \& Nayak, J.K. (2014). The measurement \& conceptualization of destination personality. Tourism Management Perspectives, 12, 88-93. https://doi.org/10.1016/j.tmp.2014.09.002

Leung, X. Y. \& Baloglu, S. (2013). Tourism Competitiveness of Asia Pacific Destinations. Tourism Analysis, 18(4), 371-384.

Lin, C. T. \& Huang, Y. L. (2009). Mining tourist imagery to construct destination image position model. Expert Systems with Applications, 36(2) 2513-24.

Lofland, J. \& Lofland, L. H. (1984). Analyzing social settings: $A$ guide to qualitative observation and analysis (2nd Ed.). Wadsworth: Belmont, ISBN10: 0534528619.

Macinnis, D. J. \& Price, L. L. (1987). The role of imagery in information processing: Review and extensions. Journal of Consumer Research, 13(4), 473-491. 
Understanding the role of destination imagery in mountain destination choice. Evidence from an exploratory research.

Malasevska, I. (2018). Explaining variation in alpine skiing frequency. Scandinavian Journal of Hospitality and Tourism, 18(2), 214-224.

Martínez de Pisón, E. (2004). El paisaje de montaña. La formación de un canon natural del paisajismo moderno. Naturaleza y cultura del paisaje. Fundación Duques de Soria y Universidad Autónoma de Madrid: Madrid, 53-121.

Martins, M. (2015). The tourist imagery, the destination imagery and the brand image. Journal of Tourism and Hospitality Management, 2(2), 1-14.

Mateiro, B., Kastenholz, E. \& Breda, Z. (2018). The sensory dimension of the tourist experience in mountain destinations: The case of Serra da Estrela Natural Park. Revista Turismo \& DesenvoIvimento, 1(27/28), 2027-2038.

Matos, N., Mendes, J. \& Pinto, P. (2015). The role of imagery and experiences in the construction of a tourism destination image. Journal of Spatial and Organizational Dynamics, 3(2), 135-154.

Mauri, C. \& Turci, L. (2018). From ski to snow: rethinking package holidays in a winter mountain destination. Worldwide Hospitality and Tourism Themes, 10(2), 201210.

Miles, M. \& Huberman, A. (1994). Qualitative data analysis: An expanded sourcebook (2nd Ed.). Sage Publications: London, ISBN-10: 0803955405.

Milijić, S., Mićić, S. \& Maksin, M. (2017). Retrospective of and prospects for the development and strategic planning of tourism in the mountain regions of Serbia. Spatium, (37), 42-48.

Miller, D. W., Hadjimarcou, J. \& Miciak, A. (2000). A scale for measuring advertisement-evoked mental imagery. Journal of Marketing Communication, 6(1), 1-20.

Moira, P. \& Drivas, P. (2017). Mountain tourism in Greece: Possibilities and prospects for extending the tourist season throughout the year. e-Journal of Science \& Technology, 12(4), 23-35.

Mu, Y. \& Nepal, S. (2016). High mountain adventure tourism: Trekkers' perceptions of risk and death in Mt. Everest Region,
Nepal. Asia Pacific Journal of Tourism Research, 21(5), 500-511.

Nepal, S. K. (2002) Mountain ecotourism. Mountain Research and Development, 22(2), pp. 104-109.

Nepal, S. K. (2011). Mountain tourism and climate change: implications for the Nepal Himalaya. Nepal Tourism \& Development Review, 1 (1), 1-13.

Nepal, S. K. \& Chipeniuk, R. (2005). Mountain tourism: Toward a conceptual framework. Tourism Geographies, 7(3), 313-333.

Nogué, J. (2005). Nacionalismo, territorio y paisaje en Cataluña. Paisaje, memoria histórica e identidad nacional. Guadalajara, Fundac. Duques de Soria-Univ. Autónoma de Madrid: Madrid, 147-170.

Ponjiger, I. (2018). Mountaineering tourism. Edited by Ghazali Musa, James Higham, and Anna Thompson-Carr. Routle. 358 pages. ISBN: 978-1-138-78237-2 (Hbk).

Price, M. F., Moss, L. A. G. \& Williams, P.W. (1997) Tourism and amenity migration. In: Mountains of the World: A Global Priority (eds. B. Messerli and J. D. Ives), Carnforth: Parthenon, pp. 249-280.

Qu, H., Kim, L. H. \& Im, H. H. (2011). A model of destination branding: Integrating the concepts of the branding and destination image. Tourism Management, 32(3), 465476.

Richins, H. (2016). Overview of Mountain Tourism: Substantive Nature, Historical Context, Areas of Focus. In Richins, H.; Hull, J.S. (Eds). Mountain Tourism Experiences, Communities, Environments and Sustainable Futures. Wallingford: $\mathrm{CAB}$ International.

Richins, H., Johnsen, S. \& Hull, J.S. (2016). Experience Provision in Mountain Tourism: Overview, Contextual Development and Emphasis. In Richins, H.; Hull, J.S. (Eds). Mountain Tourism Experiences, Communities, Environments and Sustainable Futures. Wallingford: CAB International.

Saule-Sorbé, H. (2007). El Parque Nacional de los Pirineos y el arte. In La conservación del paisaje en los parques nacionales, Servicio de Publicaciones, pp. 125-176.

Schneider, P. P. (2010). Exploring the motivation and personality traits of adventure travellers: a hierarchical model 
approach (Doctoral dissertation). United States: Michigan State University Available from ProQuest Dissertation and Theses Database. (UMINo.3435247).

Silva, C., Kastenholz, E. \& Luís Abrantes, J. (2015). Residents' Perceptions of Mountain Destinations. In Marketing Places and Spaces, Emerald Group Publishing Limited, pp. 19-31.

Smethurst, D. (2000) Mountain geography, The Geographical Review, 90(1), pp. 35-56.

Steinmetz, K. R. M., Schmidt, K., Zucker, H., \& Kensinger, E, A. (2012). The effect of Emotional arousal and retention delay on subsequent-memory effects. Cognitive Neuroscience 3(3-4), 150-159. https: //doi.org/10.1080/17588928.2012.677421

Stepchenkova, S. \& Morrison, A. M. (2008). Russia's destination image among American pleasure travelers: Revisiting Echtner and Ritchie. Tourism Management, 29(3), 548-560. https:// doi.org/10.1016/j.tourman.2007.06.003

Stylos, N., Bellou, V., Andronikidis, A. \& Vassiliadis, C. A. (2017). Linking the dots among destination images, place attachment, and revisit intentions: A study among British and Russian tourists. Tourism Management, 60, 15-29.

Tetzlaff, C., Kolodziejski, C., Markelic, I. \& Wörgötter, F. (2012). Time scales of memory, learning, and plasticity. Biological cybernetics, 106(11-12), 715-726.
Um, S. \& Crompton, L. (1990). Attitude determinants in tourism destination choice. Annals of Tourism Research, 17, 432-448. https://doi.org/10.1016/01607383(90)90008-F

Unbehaun, W., Pröbstl, U. \& Haider, W. (2008). Trends in winter sport tourism: Challenges for the future. Tourism Review, 63 (1),3647.

Woodside, A. G. \& Lysonski, S. (1989). A General Model of Traveller Destination Choice. Journal of Travel Research, 27, 814.

Yoon, Y. \& Uysal, U. (2005). An examination of the effects of motivation and satisfaction on destination loyalty: a structural model. Tourism Management, 26(1), 45-56.

Yunus, K. (2005). Mountaineering. Retrieved from The Encyclopaedia of Malaysia: 〈http://www.encyclopedia.com.my).

Zhang, Y. L., Zhang, J., Zhang, H. O., Zhang, R. Y., Wang, Y., Guo, Y. R. \& Wei, Z. C. (2017). Residents' environmental conservation behaviour in the mountain tourism destinations in China: Case studies of Jiuzhaigou and Mount Qingcheng. Journal of Mountain Science, 14(12), 2555-2567

Zimmermann, J. F., Moscovitch, M. \& Alain, C. (2016). Attending to auditory memory. Brain Research, 1640, Issue null, 208221. 